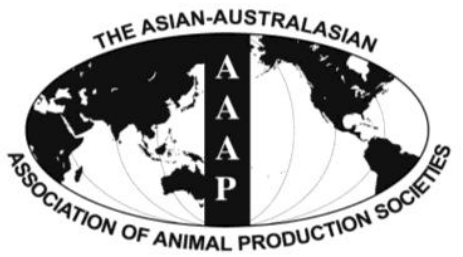

Asian-Aust. J. Anim. Sci.

Vol. 26, No. 1 : 134-142 January 2013

http://dx.doi.org/10.5713/ajas.2012.12468

www.ajas.info

pISSN 1011-2367 elSSN 1976-5517

\title{
The Effect of Modified Atmosphere Packaging and Addition of Rosemary Extract, Sodium Acetate and Calcium Lactate Mixture on the Quality of Pre-cooked Hamburger Patties during Refrigerated Storage
}

\author{
Muhlisin, Sun Moon Kang ${ }^{1}$, Won Hee Choi, Keun Taik Lee ${ }^{2}$, Sung Hee Cheong ${ }^{3}$ and Sung Ki Lee* \\ Department of Animal Products and Food Science, Kangwon National University, Chuncheon 200-701, Korea
}

\begin{abstract}
The effect of modified atmosphere packaging (MAP; $30 \% \mathrm{CO}_{2}+70 \% \mathrm{~N}_{2}$ or $100 \% \mathrm{~N}_{2}$ ) and an additive mixture (500 ppm rosemary extract, 3,000 ppm sodium acetate and 1,500 ppm calcium lactate) on the quality of pre-cooked hamburger patties during storage at $5^{\circ} \mathrm{C}$ for $14 \mathrm{~d}$ was evaluated. The addition of the additive mixture reduced aerobic and anaerobic bacteria counts in both $30 \%$ $\mathrm{CO}_{2}$ - $\mathrm{MAP}\left(30 \% \mathrm{CO}_{2}+70 \% \mathrm{~N}_{2}\right)$ and $100 \% \mathrm{~N}_{2}-\mathrm{MAP}(\mathrm{p}<0.05)$. The $30 \% \mathrm{CO}_{2}$-MAP was more effective to suppress the microbial growth than $100 \% \mathrm{~N}_{2}$-MAP, moreover the $30 \% \mathrm{CO}_{2}$-MAP combined with additive mixture resulted in the lowest bacterial counts. The hamburger patties with additive mixture showed lower CIE $\mathrm{L}^{*}$ and $\mathrm{CIE} \mathrm{a}^{*}$, and higher CIE $\mathrm{b}^{*}$ than those with no additive mixture. The $30 \% \mathrm{CO}_{2}$-MAP tended to decrease the TBARS during storage regardless of the addition of additives. The use of $30 \% \mathrm{CO}_{2}$-MAP in combination with additives mixture was effective for maintaining the quality and extending the shelf-life of pre-cooked hamburger patties. (Key Words: Rosemary Extract, Calcium Lactate, Sodium Acetate, Modified Atmosphere Packaging, Pre-cooked Hamburger Patties, Refrigerated Storage)
\end{abstract}

\section{INTRODUCTION}

Hamburger is one of the most common fast food in the world. Due to the change of life style and the growing interest in convenient foods, there is an increasing interest in the studies related with the fast food products including their packaging. Pre-cooked product is developed by food companies to answer the need for fast preparation food. Even though hamburger patties are commonly pre-cooked, the high fat contents may be prone to lipid oxidation resulting in deteriorating the quality of product during storage.

Modified atmosphere packaging (MAP) has been used by meat industries to extend the shelf-life as well as to keep the quality characteristics of meat products. During storage of cooked meat, vacuum packaging or low oxygen MAP is

\footnotetext{
* Corresponding Author: Sung Ki Lee. Tel: +82-33-250-8646, Fax: +82-33-251-7719, E-mail: skilee@kangwon.ac.kr

1 National Institute of Animal Science, Rural Development Administration, Suwon 441-706, Korea.

${ }^{2}$ Department of Food Processing and Distribution, GangneungWonju National University, Gangneung 210-702, Korea.

${ }^{3}$ Geo Food Tech Institute, Seongnam 463-741, Korea.

Submitted Sept. 3, 2012; Accepted Oct. 17, 2012; Revised Oct. 29, 2012
}

commonly used because the color changes are not a critical element as in the fresh meat. Low oxygen MAP may contain less than $20 \%$ of $\mathrm{O}_{2}$ and the rest is composed of $\mathrm{CO}_{2}$ and $\mathrm{N}_{2}$. The antibacterial effects of $\mathrm{CO}_{2}$ were documented by Renerre and Labadie (1993), Jakobsen and Bertelsen (2000), and McMillin (2008). Smith et al. (1990) suggested that 20 to $60 \%$ of $\mathrm{CO}_{2}$ in MAP is required to retard the growth of bacteria.

Besides the MAP effect, the extension of shelf-life can also be achieved by the addition of diverse additives to meat. Blom et al. (1997) reported that a mixture of $2.5 \%$ of lactate and $0.25 \%$ of acetate could be used to increase the safety of ready-to-eat cooked meat product. It was also reported that sodium acetate improved the color stability in pork (Livingston et al., 2004). Calcium lactate is generally recognized as safe food ingredient (Daengprok et al., 2002) and is commonly used in the meat industry as an antibacterial agent (Shelef and Potluri, 1995). The combined use of lactate and diacetate showed a synergistic effect on improving color stability in pork during retail display (Jensen et al., 2003) and in beef steaks (Knock et al., 2006).

Recently, there has been an increasing interest in the use of natural additives such as rosemary, tocopherols, and 
green tea, etc. in meat products due to health concerns. Rosemary has been used commercially in the meat industries due to its antioxidant activity. The antioxidant activity of rosemary is attributed to its carnosic acid, carnosol and rosmarinic acid components (Okamura et al., 1994; Frankel et al., 1996; Erkan et al., 2008). Previous studies reported the antioxidant ability of different percentages of rosemary in various meat products, such as $0.10 \%$ on pork patties (McCarthy et al., 2001), $0.25 \%$ on pork sausage (Sebranek et al., 2005), $0.10 \%$ on beef steaks (Djenane et al., 2003), and $0.03 \%$ on cooked pork patties (Lara et al., 2011).

Combinations of additives and MAP have improved the shelf-life and quality of meat. Schirmer and Langsrud (2010) reported that organic acids in combinations with $\mathrm{CO}_{2}$ MAP inhibited bacterial growth in marinated pork meat. In addition, Schirmer et al. (2009) showed that the combination of preservatives and $\mathrm{CO}_{2}$-MAP prolonged the shelf-life of salmon without negative effects on sensory characteristics. Rosemary extract combined with $30 \% \mathrm{CO}_{2}$ MAP increased the redness and reduced the lipid oxidation on cooked pork patties (Lara et al., 2011).

Studies on the effect of MAP in combination with additives mixture including natural additives and organic acid salts on the quality of pre-cooked meat products are still limited. Therefore, this study was conducted to evaluate the effect of MAP and addition of rosemary extracts, sodium acetate and calcium lactate on the storage quality of pre-cooked hamburger patties during refrigerated storage in $5^{\circ} \mathrm{C}$.

\section{MATERIALS AND METHODS}

\section{Sample preparation}

The hamburger patties were prepared by mixing $34.48 \%$ of lean meat of beef, $37.52 \%$ of pork foreleg, $6.49 \%$ of beef fat, $12.51 \%$ of onion, $5.18 \%$ of biscuit flour, $0.50 \%$ of salt, $0.15 \%$ of phosphates, $0.04 \%$ of ascorbate, $0.17 \%$ of glutamic acid, $0.60 \%$ of sugar, $0.09 \%$ of black pepper, $0.02 \%$ of dried nut, $0.43 \%$ of seasoning powder, $0.59 \%$ of starch, $0.98 \%$ of ISP (Isolated soy protein), and $0.25 \%$ of egg white powder. The beef, pork and beef fat were obtained from a local butcher in Korea. Briefly, lean meat of beef and pork foreleg were ground separately using a 6 $\mathrm{mm}$ hole plate grinder (DFFG-450, Daehan, Korea). The ingredients were mixed well using a mixer for $10 \mathrm{~min}$. A hundred grams of mixture was molded in the size of $10 \mathrm{~cm}$ diameter and $1 \mathrm{~cm}$ thickness using a hand molder (WJ-2722, Wonjee Engineering, Korea). The hamburger patties were divided into control hamburger (without additive mixture; marked as NO) and hamburger patties with added $500 \mathrm{ppm}$ of rosemary extract, 3,000 ppm of sodium acetate and 1,500 ppm of calcium lactate (marked as RO). The hamburger patties were pre-cooked until the internal temperature of patty reached $70^{\circ} \mathrm{C}$ by steam in an oven cooker (FM 2011 E3, Forno Misto, Italy).

The hamburger was cooled in a chilled room $\left(7^{\circ} \mathrm{C}\right)$ for $10 \mathrm{~min}$. A patty was placed on a polypropylene tray (max. $\mathrm{O}_{2}$ transmission rate $=0.1 \mathrm{cc} / \mathrm{cm}^{2} \cdot 24 \mathrm{~h}$ at $23^{\circ} \mathrm{C}, 0 \% \mathrm{RH}$; water vapor transmission rate $=7.87 \mathrm{mg} / \mathrm{cm}^{2} \cdot 24 \mathrm{~h}$ at $38^{\circ} \mathrm{C}$, $100 \%$ RH, Cryovac Sealed Air Corp., USA) and the trays were sealed with $\mathrm{O}_{2}$ barrier film $\left(\mathrm{O}_{2}\right.$ transmission rate = $0.39 \mathrm{cc} / \mathrm{cm}^{2} \cdot 24 \mathrm{~h}$ at $4.4^{\circ} \mathrm{C}, 100 \% \mathrm{RH}$; Lid 1050, Cryovac Sealed Air Corp., USA). The trays were filled with either $30 \% \mathrm{CO}_{2}+70 \% \mathrm{~N}_{2}$ (marked as $30 \% \mathrm{CO}_{2}-\mathrm{MAP}$ ) or $100 \% \mathrm{~N}_{2}$ (marked as $100 \% \quad \mathrm{~N}_{2}$-MAP) using a MAP machine (Hypervac, Korea) equipped with the gas mixture (MAP Mix 9001 ME, PBI Dansensor, Denmark). Carbon dioxide and nitrogen were obtained from a local gas supplier (Baekryung Specialty Gas Co., Korea). Six packs were prepared as the replication in each treatment. All packs were stored under dark condition in a refrigerator at $5^{\circ} \mathrm{C}$ for $14 \mathrm{~d}$.

\section{Headspace gas composition}

During storage, six trays from each treatment were allocated for the gas analysis, including oxygen, carbon dioxide and nitrogen. Before opening the packs, the gas composition of head space of pack was measured using a gas analyzer (DK Checkmate 9900, PBI Dansensor, Denmark).

\section{pH measurement}

Briefly, $10 \mathrm{~g}$ of sample added to $100 \mathrm{ml}$ of distilled water was homogenized at $10,000 \mathrm{rpm}$ for $60 \mathrm{~s}$ using a homogenizer (PH91, SMT Co. Ltd., Japan). The pH of the meat slurry at room temperature was measured using a $\mathrm{pH}$ meter (SevenEasy pH, Mettler-Toledo GmbH, Switzerland).

\section{Lipid oxidation}

Lipid oxidation was evaluated using 2-thiobarbituric acid (TBARS) method as described by Sinhuber and Yu (1977). An absorbance of supernatant of sample was measured at $532 \mathrm{~nm}$ using a spectrophotometer (UV-mini1240, Shimadzu Corp., Japan). The results were calculated as mg malonaldehyde (MA) per kg sample.

\section{Volatile basic nitrogen (VBN)}

The volatile basic nitrogen was determined according to Kohsaka (1975) method. The results were expressed as $\mathrm{mg} \%$.

\section{Instrumental color measurement}

Color on the surface of pre-cooked hamburger patties was monitored by measuring the CIE lightness ( $\left.\mathrm{L}^{*}\right)$, redness $\left(a^{*}\right)$ and yellowness $\left(b^{*}\right)$ using a color difference meter (CR-400, Konica Minolta Sensing Inc., Japan) and an 
illuminant $\mathrm{C}$. The color instrument was calibrated using a white plate (Illuminant $\mathrm{C}$ : $\mathrm{Y}=93.6, \mathrm{x}=0.3134$, and $\mathrm{y}=$ $0.3194)$.

\section{Aerobic and anaerobic bacteria counts}

The plate count agars (Difco, USA) were used for aerobic and anaerobic bacteria counts. Agar plates were prepared according to the manufacturer's instruction. Samples were incubated for $48 \mathrm{~h}$ at $37^{\circ} \mathrm{C}$ under normal atmospheric condition for aerobic bacteria, and anaerobic condition for anaerobic bacteria. For anaerobic bacteria incubation, the agar plates of samples were placed on an anaerobe container system, including an anaerobe box and an anaerobe paper sachet containing carbon (BD Gaspak ${ }^{\mathrm{TM}}$ EZ, Becton, Dickinson and Company, USA). Microbial populations were counted and expressed as log CFU/g.

\section{Sensory evaluation}

The hamburger patties stored under refrigeration were re-heated using a microwave (RE-2550, Samsung, Korea; $1150 \mathrm{~W}$ ) until the internal temperature reached $70^{\circ} \mathrm{C}$. The panels including faculty members and students evaluated the cooked hamburger patties on the color, taste and texture at $0,2,4$, and $6 \mathrm{~d}$ of storage. The hedonic scores of color, taste, and texture were $9=$ extremely like, $7=$ like, $5=$ moderate like, 3 = dislike, and $1=$ extremely dislike.

\section{Statistical analysis}

Three pre-cooked hamburger patties per batch and per day were used as the experimental unit. The analyses were performed in 4 repetitions in each burger patty (3 burger patties $\times 4$ replicates; $n=12$ per batch and per storage day; except sensory evaluation $\mathrm{n}=30$ and instrumental color $\mathrm{n}=$ 30). The analysis of variance (ANOVA) and Duncan's multiple range tests were carried out using the SPSS 19.0 for Windows Evaluation Version (SPSS Inc., Chicago, IL, USA).

\section{RESULTS AND DISCUSSION}

\section{Headspace gas composition}

The oxygen concentration was maintained at $0 \%$ during storage in all the treatments (data was not shown). Both in pre-cooked hamburger patties of non-added (NO) and with additive mixture (RO) packed with $30 \% \quad \mathrm{CO}_{2}-\mathrm{MAP}, \mathrm{CO}_{2}$ concentration decreased from $30 \%$ to around $28 \%$ at $2 \mathrm{~d}$ of storage and after that the carbon dioxide concentration was relatively stable until the end of storage (Table 1). Esmer et al. (2011) noted that the changes of the gas composition might be due to the results of microbial growth, the permeability of packaging material and the respiration of the meat (including gas absorption by the meat). The decrease of $\mathrm{CO}_{2}$ in MAP was the result of the absorption of $\mathrm{CO}_{2}$ into the meat (Jakobsen and Bertelsen, 2002).

In $100 \% \mathrm{~N}_{2}$-MAP, the concentration of $\mathrm{CO}_{2}$ started to increase from $8 \mathrm{~d}$ of storage in $\mathrm{NO}$ sample, while an increasing $\mathrm{CO}_{2}$ concentration in $\mathrm{RO}$ sample was noted only at $\mathrm{d}$ 14. An increased $\mathrm{CO}_{2}$ concentration may be related to the microbial growth. During storage, the microorganisms in the meat utilized the $\mathrm{O}_{2}$ in the headspace of tray while some microflora (particularly, lactic acid bacteria), produce carbon dioxide (Nychas, 1994). Jakobsen and Bertelsen

Table 1. The changes in headspace gas composition of modified atmosphere packaging (MAP) during refrigerated storage $(\% ;$ mean \pm SE, $n=4)$

\begin{tabular}{lccccc}
\hline \multirow{2}{*}{ Parameter } & Storage time & \multicolumn{3}{c}{ Treatments $^{1}$} \\
\cline { 2 - 5 } & $(\mathrm{d})$ & $\mathrm{NO}-30 \% \mathrm{CO}_{2}$ & $\mathrm{RO}-30 \% \mathrm{CO}_{2}$ & $\mathrm{NO}-100 \% \mathrm{~N}_{2}$ & $\mathrm{RO}-100 \% \mathrm{~N}_{2}$ \\
\hline $\mathrm{CO}_{2}$ & 0 & $30.0 \pm 1.0^{\mathrm{aA}}$ & $30.0 \pm 1.0^{\mathrm{aA}}$ & $0.0 \pm 0.0^{\mathrm{xC}}$ & $0.0 \pm 0.0^{\mathrm{xB}}$ \\
& 2 & $28.0 \pm 0.1^{\mathrm{bB}}$ & $28.1 \pm 0.1^{\mathrm{aB}}$ & $0.0 \pm 0.0^{\mathrm{xC}}$ & $0.0 \pm 0.0^{\mathrm{xB}}$ \\
& 6 & $28.2 \pm 0.1^{\mathrm{aB}}$ & $28.2 \pm 0.2^{\mathrm{aB}}$ & $0.1 \pm 0.1^{\mathrm{xC}}$ & $0.0 \pm 0.0^{\mathrm{xB}}$ \\
& 10 & $28.0 \pm 0.1^{\mathrm{aB}}$ & $28.0 \pm 0.1^{\mathrm{aB}}$ & $1.4 \pm 0.3^{\mathrm{xB}}$ & $0.0 \pm 0.0^{\mathrm{yB}}$ \\
$\mathrm{N}_{2}$ & $28.2 \pm 0.5^{\mathrm{aB}}$ & $27.9 \pm 0.1^{\mathrm{aB}}$ & $2.3 \pm 1.2^{\mathrm{xA}}$ & $0.4 \pm 0.2^{\mathrm{yA}}$ \\
& 14 & $70.0 \pm 1.0^{\mathrm{aA}}$ & $70.0 \pm 1.0^{\mathrm{aC}}$ & $100 \pm 0.0^{\mathrm{xA}}$ & $100 \pm 0.0^{\mathrm{xA}}$ \\
& 0 & $72.1 \pm 0.1^{\mathrm{aA}}$ & $71.9 \pm 0.1^{\mathrm{bBC}}$ & $100 \pm 0.0^{\mathrm{xA}}$ & $100 \pm 0.0^{\mathrm{xA}}$ \\
& 2 & $71.8 \pm 0.1^{\mathrm{aA}}$ & $71.7 \pm 0.1^{\mathrm{bBC}}$ & $99.9 \pm 0.1^{\mathrm{yA}}$ & $100 \pm 0.0^{\mathrm{xA}}$ \\
& 6 & $72.0 \pm 0.1^{\mathrm{aA}}$ & $72.0 \pm 0.2^{\mathrm{aAB}}$ & $99.6 \pm 0.3^{\mathrm{yAB}}$ & $100 \pm 0.0^{\mathrm{xA}}$ \\
& 10 & $71.8 \pm 0.5^{\mathrm{aA}}$ & $72.1 \pm 0.5^{\mathrm{aA}}$ & $97.7 \pm 1.2^{\mathrm{yCD}}$ & $99.6 \pm 0.2^{\mathrm{xB}}$ \\
\hline
\end{tabular}

\footnotetext{
${ }^{\mathrm{a}-\mathrm{b}}$ Values within each row (between $30 \% \mathrm{CO}_{2}$-MAP) with different superscripts are significantly different $(\mathrm{p}<0.05)$.

${ }^{\mathrm{x}-\mathrm{y}}$ Values within each row (between $100 \% \mathrm{~N}_{2}$-MAP) with different superscripts are significantly different $(\mathrm{p}<0.05)$.

${ }^{A-E}$ Values within each column with different superscripts are significantly different $(\mathrm{p}<0.05)$.

${ }^{1}$ Treatment: NO-30\% $\mathrm{CO}_{2}=$ Hamburger patties without additive mixture packed with $30 \% \mathrm{CO}_{2}+70 \% \mathrm{~N}_{2}$ NO- $100 \% \mathrm{~N}_{2}=$ Hamburger patties without additive mixture packed with $100 \% \mathrm{~N}_{2}$.

RO-30\% $\mathrm{CO}_{2}=$ Hamburger patties with added 500 ppm of rosemary extract, 3,000 ppm of sodium acetate and 1,500 ppm of calcium lactate packed with $30 \% \mathrm{CO}_{2}+70 \% \mathrm{~N}_{2}$.

RO- $100 \% \mathrm{~N}_{2}=$ Hamburger patties with added $500 \mathrm{ppm}$ of rosemary extract, 3,000 ppm of sodium acetate and 1,500 ppm of calcium lactate packed with $100 \% \mathrm{~N}_{2}$
} 
(2002) reported that both muscle respiration and microbial growth are responsible for $\mathrm{O}_{2}$ consumption and $\mathrm{CO}_{2}$ production. In our study, $0 \% \mathrm{O}_{2}$ was applied in all the packs, so that the consumption of $\mathrm{O}_{2}$ was limited. In RO samples, the production of $\mathrm{CO}_{2}$ was observed only at $\mathrm{d} 14$. The results indicated that the addition of rosemary extract and organic acid salts was effective for suppressing the growth of aerobic and anaerobic bacteria as shown in the Figures $2 \mathrm{~A}$ and $2 \mathrm{~B}$ respectively.

\section{pH value}

The $\mathrm{pH}$ value of pre-cooked hamburger patties during storage is presented in Table 2 . The $\mathrm{pH}$ value of NO sample increased after $2 \mathrm{~d}$, relatively constant until $6 \mathrm{~d}$ and then tended to decrease until the end of storage. The $\mathrm{pH}$ value of RO sample was lower $(\mathrm{p}<0.05)$ than NO samples, regardless of the type of MAP from 0 to $4 \mathrm{~d}$. The lower ph might be related with the addition of organic acids salts. For instance, Aran (2001) observed the decreasing $\mathrm{pH}$ value of a 'sous-vide' beef goulash from 6.0 to 5.5 due to the addition of $3 \%$ calcium lactate. Kim et al. (2009) reported the decrease of $\mathrm{pH}$ with calcium lactate enhancement in beef steaks. Also, Velugoti et al. (2007) reported the decrease in $\mathrm{pH}$ level of pork loin by increasing the concentration of calcium lactate. The $\mathrm{pH}$ value of $\mathrm{NO}$ samples packed with $30 \% \mathrm{CO}_{2}$-MAP was higher $(\mathrm{p}<0.05)$ than other treated hamburger patties at $\mathrm{d} 10$ and 14, while that of NO sample packed with $100 \% \mathrm{~N}_{2}$-MAP was not significantly different from $\mathrm{RO}-30 \% \mathrm{CO}_{2}$ and RO- $100 \% \mathrm{~N}_{2}(\mathrm{p}>0.05)$.

\section{Lipid oxidation}

The TBARS values of pre-cooked hamburger patties were increased as the increment of storage time in all the treatments (Table 2). The TBARS values were in a range from 0.58 to $0.79 \mathrm{mg} \mathrm{MA} / \mathrm{kg}$ sample. The addition of additive mixture delayed the lipid oxidation until $2 \mathrm{~d}$ of storage in which the TBARS values of RO samples in both in two MAP were lower compared to those of NO sample $(\mathrm{p}<0.05)$. The antioxidant activity of rosemary is attributed to its carnosic acid, carnosol and rosmarinic acid components (Erkan et al., 2008). Lara et al. (2011) reported that the TBARS value of cooked pork patties immediately after cooking ranged from 0.1 to $1.3 \mathrm{mg} \mathrm{MA} / \mathrm{kg}$ sample, and the addition of rosemary extract effectively reduced the speed lipid oxidation. Although there was no statistically significant difference, the $30 \% \mathrm{CO}_{2}$-MAP tended to delay the lipid oxidation both in NO and RO samples from 2 to 10 d. The effects of MAP were superior to the addition of rosemary and organic acids salts in detaining the lipid oxidation. The lower TBARS value in $30 \% \mathrm{CO}_{2}$-MAP may be attributed to the lower bacterial counts. At the end of storage, the TBARS value of precooked hamburger patties

Table 2. The effect of modified atmosphere packaging (MAP) and additive mixture on $\mathrm{pH}, 2$-thiobarbituric acid reactive substances (TBARS) value (mg malondialdehyde/kg sample) and volatile basic nitrogen (VBN) value (mg \%) of pre-cooked hamburger patties during refrigerated storage

\begin{tabular}{lccccc}
\hline \multirow{2}{*}{ Parameter } & Storage time & \multicolumn{4}{c}{ Treatments $^{1}$} \\
\cline { 3 - 6 } & $(\mathrm{d})$ & $\mathrm{NO}-30 \% \mathrm{CO}_{2}$ & $\mathrm{NO}-100 \% \mathrm{~N}_{2}$ & $\mathrm{RO}-30 \% \mathrm{CO}_{2}$ & $\mathrm{RO}-100 \% \mathrm{~N}_{2}$ \\
\hline $\mathrm{pH}$ & 0 & $6.65 \pm 0.01^{\mathrm{aBC}}$ & $6.65 \pm 0.01^{\mathrm{aB}}$ & $6.52 \pm 0.02^{\mathrm{bE}}$ & $6.52 \pm 0.02^{\mathrm{bE}}$ \\
& 2 & $6.79 \pm 0.05^{\mathrm{aA}}$ & $6.81 \pm 0.03^{\mathrm{aA}}$ & $6.65 \pm 0.02^{\mathrm{bC}}$ & $6.64 \pm 0.04^{\mathrm{bC}}$ \\
& 6 & $6.80 \pm 0.11^{\mathrm{aA}}$ & $6.79 \pm 0.06^{\mathrm{aA}}$ & $6.72 \pm 0.05^{\mathrm{aA}}$ & $6.77 \pm 0.02^{\mathrm{aA}}$ \\
& 10 & $6.76 \pm 0.12^{\mathrm{aAB}}$ & $6.65 \pm 0.04^{\mathrm{bB}}$ & $6.61 \pm 0.03^{\mathrm{bC}}$ & $6.63 \pm 0.01^{\mathrm{bC}}$ \\
TBARS & 14 & $6.67 \pm 0.10^{\mathrm{aBC}}$ & $6.52 \pm 0.07^{\mathrm{bC}}$ & $6.57 \pm 0.01^{\mathrm{bD}}$ & $6.56 \pm 0.01^{\mathrm{bD}}$ \\
(mg MA/kg sample) & 0 & $0.58 \pm 0.07^{\mathrm{aB}}$ & $0.58 \pm 0.07^{\mathrm{aB}}$ & $0.59 \pm 0.04^{\mathrm{aB}}$ & $0.59 \pm 0.04^{\mathrm{aD}}$ \\
& 2 & $0.69 \pm 0.07^{\mathrm{aA}}$ & $0.70 \pm 0.09^{\mathrm{aA}}$ & $0.62 \pm 0.04^{\mathrm{bB}}$ & $0.61 \pm 0.07^{\mathrm{bD}}$ \\
& 6 & $0.68 \pm 0.09^{\mathrm{aA}}$ & $0.70 \pm 0.11^{\mathrm{aA}}$ & $0.62 \pm 0.07^{\mathrm{aB}}$ & $0.64 \pm 0.08^{\mathrm{aC}}$ \\
VBN & 10 & $0.64 \pm 0.07^{\mathrm{bA}}$ & $0.72 \pm 0.11^{\mathrm{aA}}$ & $0.65 \pm 0.07^{\mathrm{bB}}$ & $0.71 \pm 0.09^{\mathrm{aB}}$ \\
$(\mathrm{mg} \%)$ & 14 & $0.72 \pm 0.08^{\mathrm{aA}}$ & $0.73 \pm 0.13^{\mathrm{aA}}$ & $0.78 \pm 0.07^{\mathrm{aA}}$ & $0.79 \pm 0.10^{\mathrm{aA}}$ \\
& 0 & $10.39 \pm 0.41^{\mathrm{aE}}$ & $10.39 \pm 0.41^{\mathrm{aD}}$ & $10.29 \pm 0.46^{\mathrm{aE}}$ & $10.29 \pm 0.46^{\mathrm{aE}}$ \\
& 2 & $10.81 \pm 1.43^{\mathrm{bE}}$ & $12.17 \pm 0.55^{\mathrm{aCD}}$ & $12.42 \pm 0.49^{\mathrm{aD}}$ & $12.84 \pm 0.51^{\mathrm{aD}}$ \\
& 6 & $13.27 \pm 1.07^{\mathrm{bD}}$ & $14.57 \pm 1.34^{\mathrm{aC}}$ & $13.80 \pm 0.45^{\mathrm{abCD}}$ & $13.73 \pm 0.93^{\mathrm{abD}}$ \\
& 10 & $19.46 \pm 0.43^{\mathrm{aC}}$ & $19.90 \pm 0.63^{\mathrm{aB}}$ & $18.36 \pm 0.90^{\mathrm{aB}}$ & $16.54 \pm 0.74^{\mathrm{bC}}$ \\
& 14 & $24.12 \pm 1.34^{\mathrm{aA}}$ & $25.52 \pm 0.69^{\mathrm{aA}}$ & $21.28 \pm 0.71^{\mathrm{bA}}$ & $21.52 \pm 0.63^{\mathrm{bA}}$ \\
\hline
\end{tabular}

\footnotetext{
${ }^{\mathrm{a}-\mathrm{b}}$ Values within each row with different superscripts are significantly different $(\mathrm{p}<0.05)$.

A-D Values within each column with different superscripts are significantly different $(\mathrm{p}<0.05)$.

${ }^{1}$ Treatment: NO-30\% $\mathrm{CO}_{2}=$ Hamburger patties without additive mixture packed with $30 \% \mathrm{CO}_{2}+70 \% \mathrm{~N}_{2}$. NO- $100 \% \mathrm{~N}_{2}=$ Hamburger patties without additive mixture packed with $100 \% \mathrm{~N}_{2}$.

RO-30\% $\mathrm{CO}_{2}=$ Hamburger patties with added 500 ppm of rosemary extract, 3,000 ppm of sodium acetate and 1,500 ppm of calcium lactate packed with $30 \% \mathrm{CO}_{2}+70 \% \mathrm{~N}_{2}$.

RO- $100 \% \mathrm{~N}_{2}=$ Hamburger patties with added $500 \mathrm{ppm}$ of rosemary extract, 3,000 ppm of sodium acetate and 1,500 ppm of calcium lactate packed with $100 \% \mathrm{~N}_{2}$.
} 
with additives tended to be higher but it was not statistically different $(p>0.05)$. T Further research is needed to confirm the pro-oxidative effect of additives mixture on precooked meat products with longer storage time.

\section{Volatile basic nitrogen}

The VBN value of pre-cooked hamburger patties was increased in all the treatments during storage $(p<0.05)$ as shown in Table 2. In NO sample, the VBN value of hamburger patties packed with $30 \% \mathrm{CO}_{2}$-MAP was lower than that of $100 \% \mathrm{~N}_{2}$-MAP from 2 until $6 \mathrm{~d}$, while from 10 to $14 \mathrm{~d}$ no statistical difference was found. This result may be attributed to the lower bacterial counts of hamburger patties packed with $30 \% \mathrm{CO}_{2}$-MAP. Protein deterioration (represented by VBN value) is associated with the activity of amino acid decarboxylase of microorganisms (Lin and Lin, 2002). In RO sample, no difference was found between $30 \% \mathrm{CO}_{2}$-MAP and $100 \% \mathrm{~N}_{2}$-MAP during storage, except at $\mathrm{d} 10$ when the VBN value of $30 \% \mathrm{CO}_{2}$-MAP was lower than that of $100 \% \mathrm{~N}_{2}$-MAP $(\mathrm{p}<0.05)$. The additive mixture tended to decrease $(p<0.05)$ the protein deterioration at the end of storage time (from 10 to $14 \mathrm{~d}$ ). It may be related to the result that the antioxidative effect of rosemary extract and organic acid salts was observed only at the end of storage. Lin and Lin (2002) noted that the addition of organic acids lowered the VBN value of Chinese style lowfat sausage. The protective effects against protein degradation of rosemary have been reported in pork patties (Haak et al., 2009), frankfurters (Estevez et al., 2005), and cooked pork patties (Lara et al., 2011).

\section{Instrumental color}

The instrumental color of pre-cooked hamburger patties including CIE $\mathrm{L}^{*}$ (lightness), $\mathrm{a}^{*}$ (redness), and $\mathrm{b}^{*}$ (yellowness) values are presented on Figure 1A, 1B, and 1C, respectively. The lightness tended to increase slightly during the storage in all treatments. In NO sample, the hamburger patties packed with $100 \% \mathrm{~N}_{2}$-MAP tended to be lighter than $30 \% \mathrm{CO}_{2}$-MAP from 2 to $14 \mathrm{~d}$, but a significant difference was observed only at d 6 . In RO sample, the lightness of hamburger patties packed with $30 \% \mathrm{CO}_{2}$-MAP tended to be higher $(\mathrm{p}<0.05)$ than $100 \% \mathrm{~N}_{2}$-MAP at the end of storage. In general, addition of additive mixture resulted in a lower lightness value than non added samples.

The redness and yellowness of pre-cooked hamburger patties fluctuated over the storage $(\mathrm{p}<0.05)$. The additive mixture lowered $(\mathrm{p}<0.05)$ the redness value in both $30 \%$ $\mathrm{CO}_{2}$-MAP and $100 \% \mathrm{~N}_{2}$-MAP over the storage. In the NO sample, redness value of hamburger patties packed with $30 \% \mathrm{CO}_{2}$-MAP was higher than $100 \% \mathrm{~N}_{2}$-MAP ( $\left.\mathrm{p}<0.05\right)$. The yellowness of NO sample was lower than RO sample $(\mathrm{p}<0.05)$. In NO samples, the $30 \% \mathrm{CO}_{2}$-MAP tended to have a higher yellowness value in the early storage time from 2 to $6 \mathrm{~d}$ and at day $14 \mathrm{~d}$ lower than $100 \% \mathrm{~N}_{2}$-MAP. No significant differences were found for yellowness value of RO sample between two packaging methods of $30 \% \mathrm{CO}_{2}$ MAP and $100 \% \mathrm{~N}_{2}$-MAP from 0 to $6 \mathrm{~d}$. Georgantelis et al. (2007) reported a decreasing trend of redness and yellowness values of beef burgers with the addition of rosemary extract during frozen storage and the decrease was strongly negatively correlated with lipid oxidation. This report was inconsistent with our results in which no clear correlation was observed between instrumental color and lipid oxidation (TBARS). Mancini and Hunt (2005) noted that the decrease of redness and yellowness is attributed to the gradual oxidation of myoglobin and accumulation of metmyoglobin.

\section{Aerobic and anaerobic bacteria counts}

The aerobic and anaerobic bacteria counts of precooked hamburger patties during the storage are presented on Figures 2A and 2B, respectively. The aerobic bacterial counts increased with prolonging the storage time in all of the treatments. The $30 \% \mathrm{CO}_{2}$-MAP delayed the growth of aerobic bacteria $(\mathrm{p}<0.05)$ both in $\mathrm{NO}$ and $\mathrm{RO}$ samples during storage. The aerobic bacterial growth in NO samples packed with $100 \% \mathrm{~N}_{2}$-MAP was faster than the other treatments.

The additive mixture effectively delayed $(p<0.05)$ the growth of aerobic bacteria during storage both in $30 \% \mathrm{CO}_{2}$ MAP and $100 \% \mathrm{~N}_{2}$-MAP. In combination with $30 \% \mathrm{CO}_{2}$ MAP, the aerobic bacterial count of RO was the lowest compared to other treatments. It means that the $30 \% \mathrm{CO}_{2}$ MAP was effective for delaying the growth of aerobic bacteria, where the effect could be enhanced by the additive mixture. The result of bacterial counts was consistent with the change of $\mathrm{CO}_{2}$ composition in the headspace of the tray, in which the $\mathrm{CO}_{2}$ composition in $100 \% \mathrm{~N}_{2}$-MAP was increased. The changing trend of anaerobic bacterial counts was similar with aerobic bacterial count, in which the $30 \%$ $\mathrm{CO}_{2}$-MAP delayed the growth of bacteria. Additive mixture showed a delaying ability against bacterial growth both in $30 \% \mathrm{CO}_{2}$-MAP and $100 \% \mathrm{~N}_{2}$-MAP and the combination of additive mixture and $30 \% \quad \mathrm{CO}_{2}$-MAP showed greater delaying effects on bacterial growth (lowest bacterial counts).

\section{Sensory evaluation}

Sensory evaluation of pre-cooked hamburger patties including color, taste, and texture is presented in Table 3. Panelists scored lower $(\mathrm{p}<0.05)$ color of RO sample than NO sample at d 0 and 2. From 4 to $6 \mathrm{~d}$, the scores of sensory color were statistically insignificant $(p>0.05)$. These observations were consistent with the redness (CIE $\left.\mathrm{a}^{*}\right)$ value instrumental color, in which the additive mixture lowered the redness during the storage. The overall likeness 

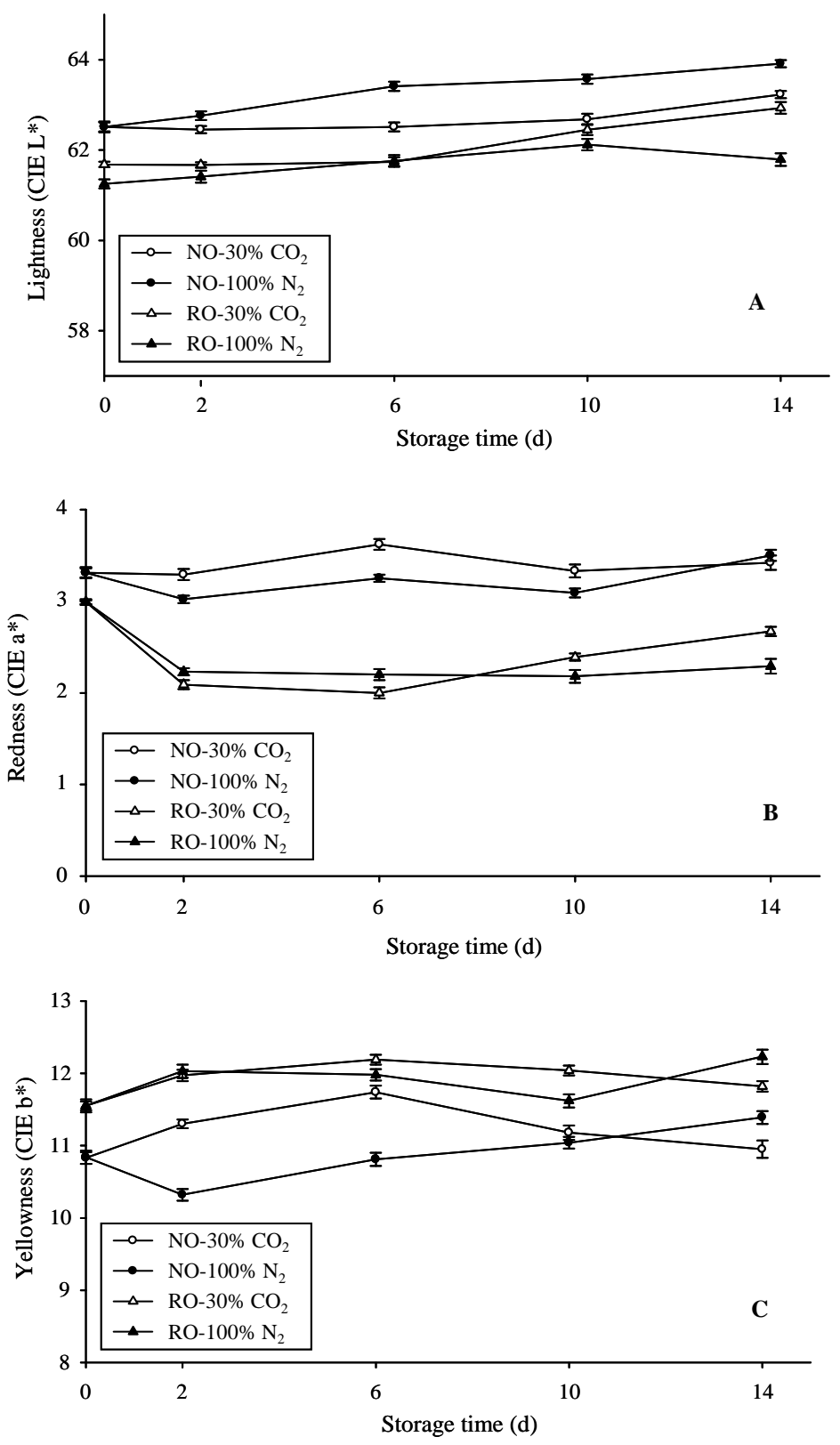

Figure 1. The effect of MAP and addition of rosemary extract, sodium acetate and calcium lactate mixture on instrumental color of lightness (CIE $\mathrm{L}^{*}$ value; A), redness (CIE $\mathrm{a}^{*}$ value; $\mathrm{B}$ ), and yellowness (CIE $\mathrm{b}^{*}$ value; $\mathrm{C}$ ) of pre-cooked hamburger patties during refrigerated storage $(\mathrm{n}=30)$. NO-30\% $\mathrm{CO}_{2}$ : Hamburger patties without additive mixture packed with $30 \% \mathrm{CO}_{2}+70 \% \mathrm{~N}_{2}$. NO-100\% $\mathrm{N}_{2}$ : Hamburger patties without additive mixture packed with $100 \% \mathrm{~N}_{2} \cdot \mathrm{RO}-30 \% \mathrm{CO}_{2}$ : Hamburger patties with added 500 ppm of rosemary extract, 3,000 ppm of sodium acetate and 1,500 ppm of calcium lactate packed with $30 \% \mathrm{CO}_{2}+70 \% \mathrm{~N}_{2}$. RO-100\% $\mathrm{N}_{2}$ : Hamburger patties with added $500 \mathrm{ppm}$ of rosemary extract, $3,000 \mathrm{ppm}$ of sodium acetate and 1,500 ppm of calcium lactate packed with $100 \% \mathrm{~N}_{2}$.

of color scores was decreased as prolonging the storage time in all of the treatments, but all the scores were still above 6 points after $6 \mathrm{~d}$ of storage. Both in the sensorial taste and texture evaluations, no differences were found between any of the treatments during the storage. In other words, the use of two different gas composition of MAP (30\% $\mathrm{CO}_{2}$-MAP and $100 \% \mathrm{~N}_{2}$-MAP) and additive mixture gave no effect on the taste and texture characteristics of precooked hamburger patties during storage.

\section{CONCLUSION}

The addition of $500 \mathrm{ppm}$ rosemary extract, 3,000 ppm sodium acetate and 1,500 ppm calcium lactate showed lower instrumental color of lightness and redness and higher yellowness of precooked hamburger patties than that of non-addition sample. The addition of these mixtures also delayed the growth of total aerobic and anaerobic bacteria. Moreover, the additive mixtures combined with the $30 \%$ $\mathrm{CO}_{2}$-MAP were more effective to suppress the microbial 

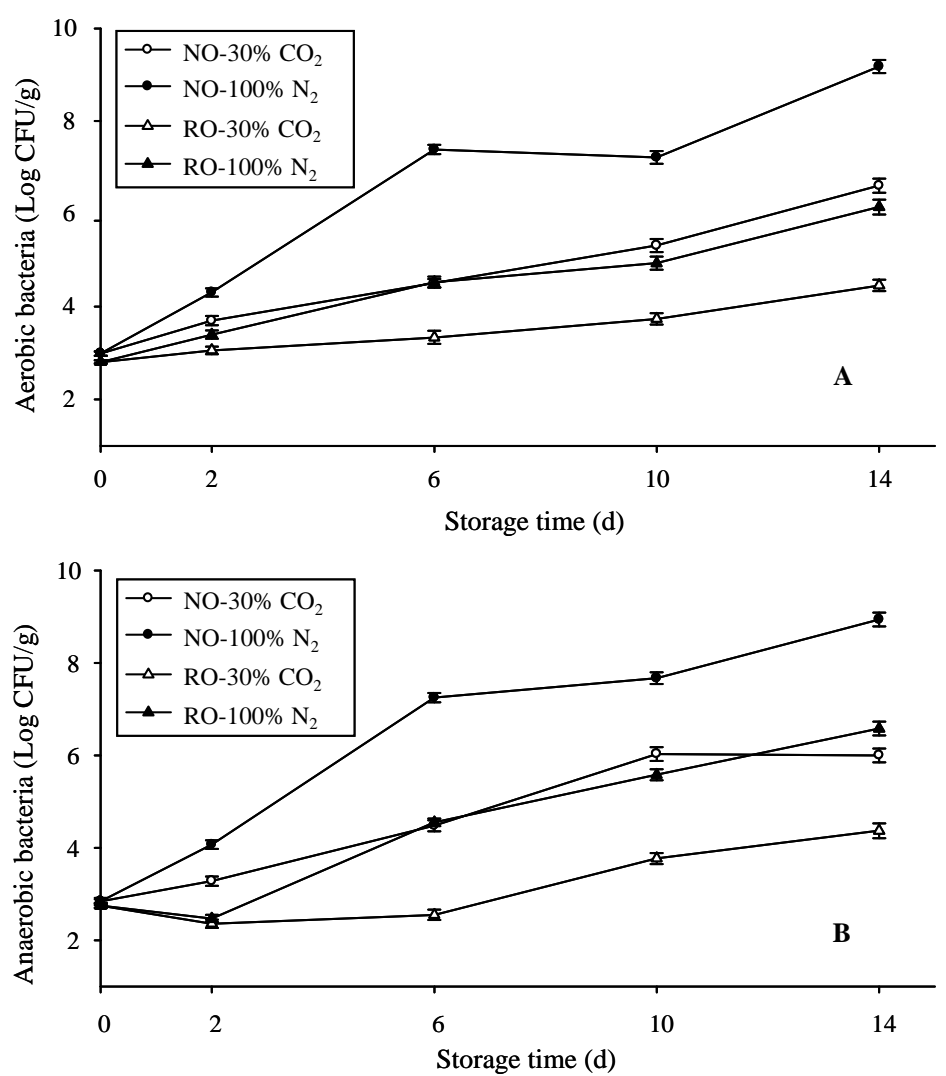

Figure 2. The effect of MAP and addition of rosemary extract, sodium acetate and calcium lactate mixture on aerobic bacterial counts (A) and anaerobic bacterial counts (B) (Log CFU/g unit; $n=12$ ) of pre-cooked hamburger patties during refrigerated storage.

Table 3. The effect of modified atmosphere packaging (MAP) and additive mixture on the sensory evaluation of pre-cooked hamburger patties during refrigerated storage

\begin{tabular}{llllll}
\hline \multirow{2}{*}{ Parameters } & Treatment & \multicolumn{4}{c}{ Storage time $(\mathrm{d})$} \\
\cline { 3 - 6 } Color & $\mathrm{NO}-30 \% \mathrm{CO}_{2}$ & $8.5 \pm 0.6^{\mathrm{aA}}$ & $8.0 \pm 0.4^{\mathrm{aAB}}$ & $7.5 \pm 0.8^{\mathrm{aB}}$ & $7.0 \pm 0.2^{\mathrm{aC}}$ \\
& $\mathrm{NO}-100 \% \mathrm{~N}_{2}$ & $8.4 \pm 0.5^{\mathrm{aA}}$ & $7.9 \pm 0.5^{\mathrm{aAB}}$ & $7.2 \pm 0.5^{\mathrm{aB}}$ & $7.2 \pm 0.6^{\mathrm{aB}}$ \\
& $\mathrm{RO}-30 \% \mathrm{CO}_{2}$ & $7.2 \pm 0.7^{\mathrm{bA}}$ & $7.3 \pm 0.6^{\mathrm{bA}}$ & $6.8 \pm 0.2^{\mathrm{aAB}}$ & $6.5 \pm 0.3^{\mathrm{aB}}$ \\
& $\mathrm{RO}-100 \% \mathrm{~N}_{2}$ & $7.5 \pm 0.5^{\mathrm{bA}}$ & $7.3 \pm 04^{\mathrm{bA}}$ & $6.9 \pm 0.6^{\mathrm{aAB}}$ & $6.8 \pm 0.3^{\mathrm{aB}}$ \\
Taste & $\mathrm{NO}-30 \% \mathrm{CO}_{2}$ & $8.4 \pm 0.5^{\mathrm{aA}}$ & $8.1 \pm 0.5^{\mathrm{aAB}}$ & $7.9 \pm 0.5^{\mathrm{aAB}}$ & $7.6 \pm 0.5^{\mathrm{aB}}$ \\
& $\mathrm{NO}-100 \% \mathrm{~N}_{2}$ & $8.2 \pm 0.5^{\mathrm{aA}}$ & $8.0 \pm 0.6^{\mathrm{aA}}$ & $8.0 \pm 0.6^{\mathrm{aA}}$ & $7.5 \pm 0.8^{\mathrm{aB}}$ \\
& $\mathrm{RO}-30 \% \mathrm{CO}_{2}$ & $8.5 \pm 0.6^{\mathrm{aA}}$ & $8.2 \pm 0.6^{\mathrm{aAB}}$ & $8.0 \pm 0.8^{\mathrm{aAB}}$ & $7.6 \pm 0.7^{\mathrm{aB}}$ \\
& $\mathrm{RO}-100 \% \mathrm{~N}_{2}$ & $8.6 \pm 0.4^{\mathrm{aA}}$ & $8.3 \pm 0.4^{\mathrm{aA}}$ & $7.8 \pm 0.5^{\mathrm{aAB}}$ & $7.5 \pm 0.6^{\mathrm{aB}}$ \\
Texture & $\mathrm{NO}-30 \% \mathrm{CO}_{2}$ & $7.4 \pm 1.0^{\mathrm{aA}}$ & $7.2 \pm 0.8^{\mathrm{aA}}$ & $7.1 \pm 0.5^{\mathrm{aA}}$ & $7.0 \pm 0.5^{\mathrm{aA}}$ \\
& $\mathrm{NO}-100 \% \mathrm{~N}_{2}$ & $7.2 \pm 0.6^{\mathrm{aA}}$ & $7.6 \pm 0.6^{\mathrm{aA}}$ & $7.0 \pm 0.6^{\mathrm{aA}}$ & $6.9 \pm 0.6^{\mathrm{aA}}$ \\
& $\mathrm{RO}-30 \% \mathrm{CO}_{2}$ & $7.3 \pm 0.8^{\mathrm{aA}}$ & $7.1 \pm 0.4^{\mathrm{aA}}$ & $7.3 \pm 0.9^{\mathrm{aA}}$ & $6.9 \pm 0.4^{\mathrm{aA}}$ \\
& $\mathrm{RO}-100 \% \mathrm{~N}_{2}$ & $7.5 \pm 0.8^{\mathrm{aA}}$ & $7.2 \pm 0.6^{\mathrm{aA}}$ & $7.1 \pm 0.5^{\mathrm{aA}}$ & $6.8 \pm 0.8^{\mathrm{aA}}$ \\
\hline
\end{tabular}

${ }^{\mathrm{a}-\mathrm{b}}$ Values within each column with different superscripts are significantly different $(\mathrm{p}<0.05)$.

A-D Values within each row with different superscripts are significantly different $(\mathrm{p}<0.05)$.

The hedonic scores: $9=$ extremely like, $7=$ like, $5=$ moderate like, $3=$ dislike, and $1=$ extremely dislike.

${ }^{1}$ Treatment: NO-30\% $\mathrm{CO}_{2}=$ Hamburger patties without additive mixture packed with $30 \% \mathrm{CO}_{2}+70 \% \mathrm{~N}_{2}$.

NO-100\% $\mathrm{N}_{2}=$ Hamburger patties without additive mixture packed with $100 \% \mathrm{~N}_{2}$.

RO-30\% $\mathrm{CO}_{2}=$ Hamburger patties with added $500 \mathrm{ppm}$ of rosemary extract, 3,000 ppm of sodium acetate and 1,500 ppm of calcium lactate packed with $30 \% \mathrm{CO}_{2}+70 \% \mathrm{~N}_{2}$.

RO- $100 \% \mathrm{~N}_{2}=$ Hamburger patties with added $500 \mathrm{ppm}$ of rosemary extract, 3,000 ppm of sodium acetate and 1,500 ppm of calcium lactate packed with $100 \% \mathrm{~N}_{2}$ 
growth than that of $100 \% \mathrm{~N}_{2}$-MAP. The $30 \% \mathrm{CO}_{2}$-MAP itself tended to decrease the lipid deterioration (TBARS) regardless of the addition of additives. The conclusion is that the use of $30 \% \mathrm{CO}_{2}$-MAP in combination with the addition of rosemary extract, sodium acetate and calcium lactate was effective for maintaining the quality and extending the shelf-life of pre-cooked hamburger patties during refrigerated storage at $5^{\circ} \mathrm{C}$.

\section{ACKNOWLEDGEMENTS}

This research was supported by Technology Development Program for Agriculture and Forestry (108061-03-2-HD120), Ministry for Food, Agriculture, Forestry and Fisheries, Republic of Korea.

\section{REFERENCES}

Aran, N. 2001. The effects of calcium and sodium lactates on growth from spores of Bacillus cereus and Clostridium perfringens in a 'sous-vide' beef goulash under temperature abuse. Int. J. Food Microbiol. 63:117-123.

Blom, H., E. Nerbrink, R. Dainty, T. Hagtvedt, E. Borch, H. Nissen and T. Nesbakken. 1997. Addition of $2.5 \%$ lactate and $0.25 \%$ acetate controls growth of Listeria monocytogenes in vacuum-packed, sensory-acceptable servelat sausage and cooked ham stored at $4^{\circ} \mathrm{C}$. Int. J. Food Microbiol. 38:71-79.

Daengprok, W., W. Garnjanagoonchorn and Y. Mine. 2002. Fermented pork sausage fortified with commercial or hen eggshell calcium lactate. Meat Sci. 62:199-204.

Djenane, D., A. Sanchez-Escalante, J. A. Beltran and P. Roncales. 2003. Extension of the shelf life of beef steaks packaged in modified atmosphere by treatment with rosemary and displayed under UV-free lighting. Meat Sci. 64:417-426.

Erkan, N., G. Ayranci and E. Ayranci. 2008. Antioxidant activities of rosemary (Rosmarinus Officinalis L.) extract, blackseed (Nigella sativa L.) essential oil, carnosic acid, rosmarinic acid and sesamol. Food Chem. 110:76-82.

Esmer, O. K., R. Irkin, N. Degirmencioglu and A. Degirmencioglu. 2011. The effect of modified atmosphere gas composition on microbial criteria, color and oxidation values of minced beef meat. Meat Sci. 88:221-226.

Estevez, M., S. Ventanas and R. Cava. 2005. Protein oxidation in Frankfurters with increasing levels of added rosemary essential oil: Effect on color and texture deterioration. J. Food Sci. 70:c427-c432.

Frankel, E. N., S. W. Huang, R. Aeschbach and E. Prior. 1996. Antioxidant activity of a rosemary extract and its constituents, carnosic acid, carnosol, and rosmarinic acid, in bulk oil and oil-in-water emulsion. J. Agric. Food Chem. 44:131-135.

Georgantelis, D., G. Blekas, P. Katikou, I. Ambrosiadis and D. J. Fletouris. 2007. Effect of rosemary extract, chitosan and $\alpha$ tocopherol on lipid oxidation and colour stability during frozen storage of beef burgers. Meat Sci. 75:256-264.

Haak, L., K. Raes and S. De Smet. 2009. Effect of plant phenolic, thocopherol, and ascorbic acid on oxidative stability of pork patties. J. Sci. Food Agric. 89:1360-1365.
Jakobsen, M. and G. Bertelsen. 2000. Color stability and lipid oxidation of fresh beef. Development of a response surface model for predicting the effects of temperature, storage time, and modified atmosphere composition. Meat Sci. 54:49-57.

Jakobsen, M. and G. Bertelsen. 2002. The use of $\mathrm{CO}_{2}$ in packaging of fresh red meats and its effect on chemical quality of changes in the meat: A review. J. Muscle Foods 13:143-168.

Jensen, J. M., K. L. Robbins, K. J. Ryan, C. Homco-Ryan, F. K. McKeith and M. S. Brewer. 2003. Effects of lactic and acetic acid salts on quality characteristics of enhanced pork during retail display. Meat Sci. 63:501-508.

Kim, Y. H., J. T. Keeton, S. B. Smith, J. E. Maxim, H. S. Yang and J. W. Savell. 2009. Evaluation of antioxidant capacity and color stability of calcium lactate enhancement on fresh beef under highly oxidizing condition. Food Chem. 115:272-278.

Knock, R. C., M. Seyfert, M. C. Hunt, M. E. Dikeman, R. A. Mancini, J. A. Unruh, J. J. Higgins and R. A. Monderen. 2006. Effects of potassium lactate, sodium chloride, sodium tripolyphosphate, and sodium acetate on colour, colour stability, and oxidative properties of injection-enhanced beef rib steaks. Meat Sci. 74:312-318.

Kohsaka, K. 1975. Freshness preservation of food and measurement. Food Ind. 18:105-111.

Lara, M. S., J. I. Gutierrez, M. Timon and A. I. Andres. 2011. Evaluation of two natural extract (Rosmarinus officinalis L. and Meissa officinalis L.) as antioxidants in cooked pork patties packed in MAP. Meat Sci. 88:481-488.

Lin, K. W. and S. H. Lin. 2002. Effects of sodium lactate and trisodium phosphate on the physicochemical properties and shelf-life of low-fat Chinese-style sausage. Meat Sci. 60:14754.

Livingston, M., M. S. Brewer, J. Killifer, B. Bidner and F. McKeith. 2004. Shelf-life characteristics of enhanced modified atmosphere packaged pork. Meat Sci. 68:115-122.

Mancini, R. A. and M. C. Hunt. 2005. Current research in meat colour. Meat Sci. 71:100-121.

McCarthy, T. L., J. P. Kerry, J. F. Kerry, P. B. Lynch and D. J. Buckley. 2001. Assessment of the antioxidant potential of natural food and plant extracts in fresh and previously frozen pork patties. Meat Sci. 57:177-184.

McMillin, K. W. 2008. Where is MAP Going? A review and future potential of modified atmosphere packaging for meat: review. Meat Sci. 80:43-65.

Nychas, G. J. E. 1994. Modified atmosphere packaging of meat. In: Minimal processing of foods and process optimization (Ed. R. P. Singh and F. A. R. Oliviera). An Interface CRC Press, London. pp. 417-436.

Okamura, N., Y. Fujimoto, S. Kuwabara and A. Yagi. 1994. High performance liquid chromatography determination of carnosic acid and carnosol in Rosmarinus officinalis and Salvia officinalis. J. Chrom. A. 679:381-386.

Renerre, M. and J. Labadie. 1993. Proceedings of the 39th International Congress of Meat Science and Technology, 1993 August 1-6; Calgary, AB.

Schirmer, B. C., R. Heiberg, T. Eie, T. Møretrø, T. Maugesten, M. Carlehøg and S. Langsrud. 2009. A novel packaging methods with dissolving $\mathrm{CO}_{2}$ headspace combined with organic acids prolongs the self-life of fresh salmon. Int. J. Food Microbiol. 133:154-160. 
Schirmer, B. C. and S. Langsrud. 2010. A dissolving $\mathrm{CO}_{2}$ headspace combined with organic acids prolonged the shelflife of fresh pork. Meat Sci. 85:280-284.

Sebranek, J. G., V. J. H. Sewalt, K. L. Robbins and T. A. Houser. 2005. Comparison of a natural rosemary extract and BHA/BHT for relative antioxidant effectiveness in pork sausage. Meat Sci. 69:289-296.

Shelef, L. A. and V. Potluri. 1995. Behaviour of foodborne pathogens in cooked liver sausage-containing lactates. Food Microbiol. 12:221-227.
Sinhuber, R. O. and T. C. Yu. 1977. The 2-thiobarbituric acid reaction, an objective measure of the oxidative deterioration occurring in fat and oil. J. Jap. Soc. Fish. Sci. 26:259-67.

Smith, J. P., H. S. Ramaswamy and B. K. Simpson. 1990. Development in food packaging technology. Part II. Storage aspects. Trends Food Sci. Technol. 1:111-118.

Velugoti, P. R., L. Rajagopal, V. Juneja and H. Thippareddi. 2007. Use of calcium, potassium, and sodium lactates to control germination and outgrowth of Clostridium perfringens spores during chilling of injected pork. Food Microbiol. 24:687-694. 